\title{
DOSSIÊ - VINTE ANOS SEM MURO EM BERLIM Novas faces da violência política
}

\section{Apresentação Sebastião Nascimento}

A queda do muro de Berlim e a noção de "guerra contra o terror", que se apresentou como resposta aos ataques de 11 de setembro de 2001 em Nova York, emergem repetidamente como marcos simbólicos de grandes transformaçôes ocorridas nos sistemas políticos do mundo todo, tanto a leste como a oeste da velha linha de oposição das grandes alianças militares, mas também de transformaçôes ainda em curso e à espera de interpretaçôes convincentes. Nas últimas duas décadas, observamos o fim de velhas e a emergência de novas unidades políticas - as unificações da Alemanha e do Iêmen, a desintegração da Checoslováquia, da Iugoslávia e da União Soviética, a secessão de países como Eritreia, Timor-Leste e Kosovo -, bem como a expansão de esforços de integração política e econômica, a absorção de diversos antigos membros do Pacto de Varsóvia no seio da Otan, o envolvimento de inúmeros exércitos nacionais em esforços de manutenção da paz sob os auspícios da ONU e a mobilização de outros tantos na tentativa de conter, combater ou simplesmente definir o terrorismo como fenômeno político.

As duas décadas que nos separam da queda do muro de Berlim e do fim da Guerra Fria representam um período em que um conjunto de transformaçōes radicais nas formas de autoconfiguração de grupos sociais, bem como nas formas de manifestação de suas demandas políticas, estabeleceu um novo panorama de questôes para as ciências sociais. A dissolução simbólica e o desmonte institucional de um conjunto de entidades mais visíveis prenunciaram o fenômeno, mas de certa forma ele evoluiu de modo mais ou menos paralelo num conjunto imensamente mais amplo de casos.

Um amplo debate se espraia atualmente por todos os âmbitos das ciências sociais e humanidades, ainda que no mais das vezes apoiado em contribuições que seguem caminhos paralelos, sem se apoiarem nos avanços e nas descobertas de seus correlatos em campos disciplinares diferentes. Inúmeras inter- 
pretações, algumas mais complexas e sutis, outras nem tanto, circulam sobre o sentido e os resultados dos eventos que marcaram esse período. Contudo, um esforço comum move todos os envolvidos nessas discussões, a saber, a tentativa de encontrar as ferramentas e um terreno comum para compreender a articulação entre os novos elementos presentes na realidade histórica dessa nova fase e o estatuto de validade dos elementos antigos que nela se preservam, mesmo que sob uma roupagem distinta.

A mesa-redonda que resultou neste Dossiê de modo algum procura se apresentar como um balanço exaustivo desses esforços, mas tão somente procurar ressaltar pontos de contato entre empreendimentos intelectuais diversos e dar um passo adiante na elaboração de uma pauta comum de investigação, capaz de fazer convergir o que por vezes se apresenta como incontrastável ou imiscível.

Duas décadas após a reunificação alemã, segue vívida a sensação amplamente compartilhada de que as bases do mundo moderno passaram por um processo de reacomodação, e é com esse conjunto de questóes em mente que procuramos reunir nesta mesa-redonda dois antropólogos e dois sociólogos de gerações diferentes que procuram enfrentar essas transformaçôes, cada um de uma perspectiva diferente, mas igualmente instigante, invocando e interpelando o debate contemporâneo em torno delas, assim como a validade das categorias que vêm sendo mobilizadas para levá-lo adiante.

Hauke Brunkhorst é professor de sociologia e filosofia política e diretor do Departamento de Sociologia da Universidade de Flensburg e detentor da prestigiosa cátedra Theodor Heuss da New School for Social Research da Universidade de New York. Sua área de trabalho estende-se da constitucionalização no processo de integração europeia ao papel desempenhado pelas relações de solidariedade na sustentação das instituições democráticas e no reajuste das bases de integração em sociedades plurais, passando por uma aguda avaliação das implicações dos processos de secularização na transformação das estruturas sociais e políticas das sociedades pós-industriais e abrangendo publicaçôes de intervenção mais direta em debates em curso, sobretudo em torno da renitência e da difusão da tortura, dos esforços de superação da distância sim- bólica e institucional entre centro e periferia de sistemas políticos, das implicações entre a integração europeia e a integração sul-americana, da juridicização das relações internacionais e das variações de consolidação do discurso de direitos humanos.

João de Pina Cabral, professor titular do Instituto de Ciências Sociais da Universidade de Lisboa, vem sistematicamente enfrentando a antropologia aos dilemas do mundo contemporâneo - e vice-versa - e recentemente foi autor de uma instigante reflexão sobre o lugar da "guerra contra o terror", e do que usualmente se define como terrorismo, no cenário das ciências sociais nos Estados Unidos.

Florian Mühlfried é antropólogo do Max Planck Institute for Social Anthropology (Alemanha) que há anos desenvolve pesquisa na região do Cáucaso, mais precisamente na Geórgia. Faz parte de uma geração de antropólogos que procurou fazer uso da tradição etnográfica para compreender os processos de transformação em curso em regiōes pós-socialistas da Eurásia e é com os dilemas implicados na construção democrática, as tensões que acompanham um redesenho sempre inadequado de fronteiras políticas e nacionais e os conflitos entre os cidadãos e uma nova estrutura política que se deparou Mühlfried na Geórgia. Este pequeno Estado caucasiano sofre ainda a ameaça da fragmentação, consequência de nacionalismos secessionistas apoiados pela Federação Russa, potência ciosa de manter a hegemonia na região.

Sebastiāo Nascimento, jovem doutor ora engajado na coordenação de um abrangente projeto de pesquisa voltado aos conflitos internacionais contemporâneos na Unicamp, incorpora em seu trabalho várias das preocupações que motivaram a proposição desta mesa-redonda - desde a busca por uma compreensão mais apurada sobre a formação do nacionalismo histórico, passando pela abordagem das variações do discurso democrático, até as questões mais contemporâneas relacionadas com os limites do discurso dos direitos humanos e as reformulaçōes de demandas por autodeterminação política.

A Anpocs sempre se caracterizou pelo enfrentamento de temáticas contemporâneas. É com este espírito, e com a intenção de promover o encontro de cientistas sociais brasileiros com estrangeiros, que esta mesa-redonda foi realizada. Celebrar a passa- 
gem dessas duas décadas de intensas transformações e reajustes de estruturas políticas, econômicas e sociais e dos sentidos que lhes são atribuídos por meio da realização de uma mesa-redonda de perfil internacional, envolvendo pesquisadores de disciplinas, países e gerações diferentes, foi uma oportunidade única, e o registro desse debate nas páginas desta edição da Revista Brasileira de Ciências Sociais certamente contribuirão para ampliar o acesso às ideias que pautaram a discussão intensa e vibrante que se realizou naquele Encontro Nacional da Anpocs. 


\section{VINTE ANOS SEM MURO EM BERLIM}

Florian Mühlfried, Hauke Brunkhorst, João de Pina-Cabral e Sebastião Nascimento

Palavras-chave: Reunificação alemã; Nacionalidade; Ordem global; Terrorismo.

Duas décadas após a reunificação alemã, segue vívida a sensação amplamente compartilhada de que as bases do mundo moderno passaram por um processo de reacomodação e é com esse conjunto de questôes em mente que procuramos reunir neste Dossiê dois antropólogos e dois sociólogos de geraçōes diferentes que procuram enfrentar essas transformações, cada um de uma perspectiva diferente, mas igualmente instigante, invocando e interpelando o debate contemporâneo em torno delas, assim como a validade das categorias que vêm sendo mobilizadas para levá-lo adiante.

\section{TWENTY YEARS WITHOUT THE BERLIN WALL}

Florian Mühlfried, Hauke Brunkhorst, João de Pina-Cabral, and Sebastião Nascimento

Keywords: German reunification; $\mathrm{Na}-$ tionality; Global order; Terrorism.

Two decades after the German reunification, the widely shared sensation of some rearrangement in the basis of the modern world has still been vivid, and it is with such matters in mind that we have gathered in this dossier two anthropologists and two sociologists from different generations who aim at facing these transformations, each one from his unique though equally intriguing perspective, invoking and interpellating a contemporary debate around them, as well as the validity of the categories that have been mobilized in order to carry it out.

\section{VINGT ANS SANS LE MUR DE BERLIN}

\section{Florian Mühlfried, Hauke Brunkhorst, João de Pina-Cabral et Sebastião Nascimento}

Mots-clés: Réunification allemande; $\mathrm{Na}$ tionalité; Ordre global; Terrorisme.

Deux décennies après la réunification allemande, la sensation selon laquelle les bases du monde moderne sont passées par un processus de réadaptation, reste toujours vivante et largement partagée. Ayant à l'esprit cet ensemble de questions, nous avons tenté de réunir, dans ce dossier, deux anthropologues et deux sociologues de générations différentes. Ils cherchent, chacun par une perspective différente mais tout aussi instigatrice, à comprendre ces transformations en invoquant et en interpellant le débat contemporain existant autour d'elles, ainsi que la validité des catégories qui sont entrain d'être mobilisées pour le faire avancer. 